\title{
Abnormalities of cerebrospinal fluid amino acids in patients with the Guillain-Barré syndrome
}

\author{
R N CORSTON, E H F M G ALE, C STONIER, G M ABER, \\ A N D E C H U T CHINSON \\ From the Departments of Neurology and Nephrology, North Staffordshire Hospital Centre, \\ Stoke-on-Trent, Staffordshire
}

SU M MARY Measurements of cerebrospinal fluid (CSF) and plasma amino acid concentrations have been made in 12 patients with the Guillain-Barré syndrome. The CSF protein concentration was normal in seven specimens and raised in 13. Abnormalities of the CSF amino acid profile were found in all specimens but were more marked in those with a raised CSF protein concentration. The possible causes and diagnostic significance of these changes are discussed.

The concentration of amino acids in the cerebrospinal fluid (CSF) of normal individuals is much lower than that of the plasma. ${ }^{1}$ Small disturbances of the CSF amino acid profile have been described in various neurological diseases such as Parkinsonism, ${ }^{2}$ epilepsy, ${ }^{3}$ and Huntington's chorea; ${ }^{4}$ the most marked abnormalities have been found in patients with purulent meningitis where the changes were thought largely to result from a breakdown of the blood-CSF barrier. ${ }^{5}$

The Guillain-Barré syndrome is associated with a rise in the CSF protein concentration at some stage of the disease and it is claimed that this largely results from a breakdown of the bloodCSF barrier. ${ }^{6-11}$ The present study was therefore designed to see if there was a change in the CSF amino acid profile in this disorder accompanying the rise in protein concentration.

\section{Patients studied}

Twelve patients were studied. Details of age, sex and the CSF protein concentrations and white cell counts are shown in table 1 . Six of the patients were male and six female. Their mean age was 40.3 years (range 11-68 years). All conformed to the diagnostic criteria

Address for reprint requests: RN Corston, Department of Neurology, General Hospital, Park Row, Nottingham, NG1 6HA .

Accepted 6 November 1980 for the Guillain-Barré syndrome as proposed by the American National Institute of Neurological and Communicative Disorders and Stroke. ${ }^{12}$

Simultaneous specimens of lumbar CSF and venous blood were collected after an overnight fast of 12-18 hours. Five patients had their CSF and plasma amino acid concentrations measured on one occasion only; six on two occasions and in one patient they were measured on three occasions. The specimens were obtained between the 5th and 63rd days after the development of neurological symptoms. Although all but one patient (EP) were treated with either ACTH or oral steroids samples of CSF and blood were obtained from six patients before treatment started.

Analysis of specimens The specimens of CSF and venous blood were centrifuged $\left(4000 \mathrm{~g}, 10 \mathrm{~min}, 4^{\circ} \mathrm{C}\right)$, deproteinised and stored at $-20^{\circ} \mathrm{C}$. They were analysed for their free amino acid concentration as described previously. ${ }^{1}$ Glutamine and glutamic acid concentrations were measured on an aliquot of the same specimen by a double enzymatic procedure. ${ }^{13} \mathrm{~A}$ sample of each CSF specimen was examined by microscopy and cultured for bacteria and viruses. Measurements of protein and sugar concentrations and a differential white cell count were carried out using standard laboratory procedures. Serological tests for syphilis were carried out on each specimen and all were negative. Each patient had virus antibody titres in the serum measured on two occasions and no abnormally raised values were found. One patient (CW) had a positive Paul Bunnel test together with atypical lymphocytes in the blood confirming a diagnosis of infectious mononucleosis. 
Analysis of results Total and individual amino acid concentrations were compared with normal values ${ }^{1}$ using the Wilcoxon Rank Sum Test.

\section{Results}

The significant changes in CSF and venous plasma amino acid concentrations are shown in table 2 . There was a significant increase in the total CSF amino acid concentration but no significant change in the total plasma amino acid concentration. The CSF concentrations of 12 individual amino acids (ornithine, lysine, arginine, glycine, alanine plus citrulline, 2 amino-butyric acid, valine, isoleucine, leucine, tyrosine and phenylalanine) were signifi- cantly increased; only six of these (alanine plus citrulline, 2 amino-butyric acid, leucine, ornithine and lysine) were significantly increased when the CSF protein concentration was normal. Only four plasma amino acids (phenylalanine, lysine, ornithine and aspartic acid) were present in significantly increased concentrations. There were significant reductions in the concentrations of three amino acids in the CSF (phosphoethanolamine, serine and glutamic acid) and of five in the plasma (threonine, serine, glutamine, proline and histidine).

CSF white cell count The CSF white cell count was raised in only two patients (EP and CW) and thus there was no correlation between CSF white

Table 1 Details of patients studied and laboratory details of the CSF specimens

\begin{tabular}{|c|c|c|c|c|c|c|}
\hline \multirow[t]{2}{*}{ Patient } & \multirow[t]{2}{*}{ Sex } & \multirow[t]{2}{*}{ Age (yr) } & \multicolumn{2}{|l|}{ 1st specimen } & \multicolumn{2}{|l|}{ 2nd specimen } \\
\hline & & & Protein $(g / l)$ & $\begin{array}{l}\text { white cell count } \\
\left(\text { per } \mathrm{mm}^{3}\right)\end{array}$ & Protein $(g / l)$ & $\begin{array}{l}\text { white cell count } \\
\left(\text { per } \mathrm{mm}^{3}\right)\end{array}$ \\
\hline PBa & $\mathbf{F}$ & 25 & 0.70 & 1 & - & - \\
\hline DB & $\mathbf{M}$ & 26 & 0.20 & 4 & 0.35 & 3 \\
\hline PBo & $\mathbf{M}$ & 33 & 0.35 & 0 & 0.30 & 0 \\
\hline LB & $\mathbf{M}$ & 62 & 0.90 & 0 & 1.00 & 0 \\
\hline SB & $\mathbf{F}$ & 29 & 1.60 & 0 & 1.60 & 1 \\
\hline DC & $\mathbf{M}$ & 28 & 0.85 & 1 & - & - \\
\hline GD & $F$ & 68 & 0.25 & 2 & 0.25 & 1 \\
\hline JH & $M$ & 38 & $3 \cdot 20$ & 4 & 1.40 & 1 \\
\hline EP & $\mathbf{F}$ & 44 & $1 \cdot 10$ & 20 & - & - \\
\hline AS & $\mathbf{M}$ & 65 & 0.90 & 0 & 0.95 & 1 \\
\hline HS & $\mathbf{F}$ & 54 & 0.55 & 1 & $6 \cdot 40$ & 3 \\
\hline $\mathrm{CW}^{*}$ & $\mathbf{F}$ & 11 & 0.35 & 21 & - & - \\
\hline
\end{tabular}

*Positive Paul Bunnel test and atypical lymphocytes in the peripheral blood.

Table 2 Significant changes in CSF and venous plasma amino acid concentration in patients with the Guillain-Barré syndrome. All values in micromoles per litre (mean $\pm S D)$

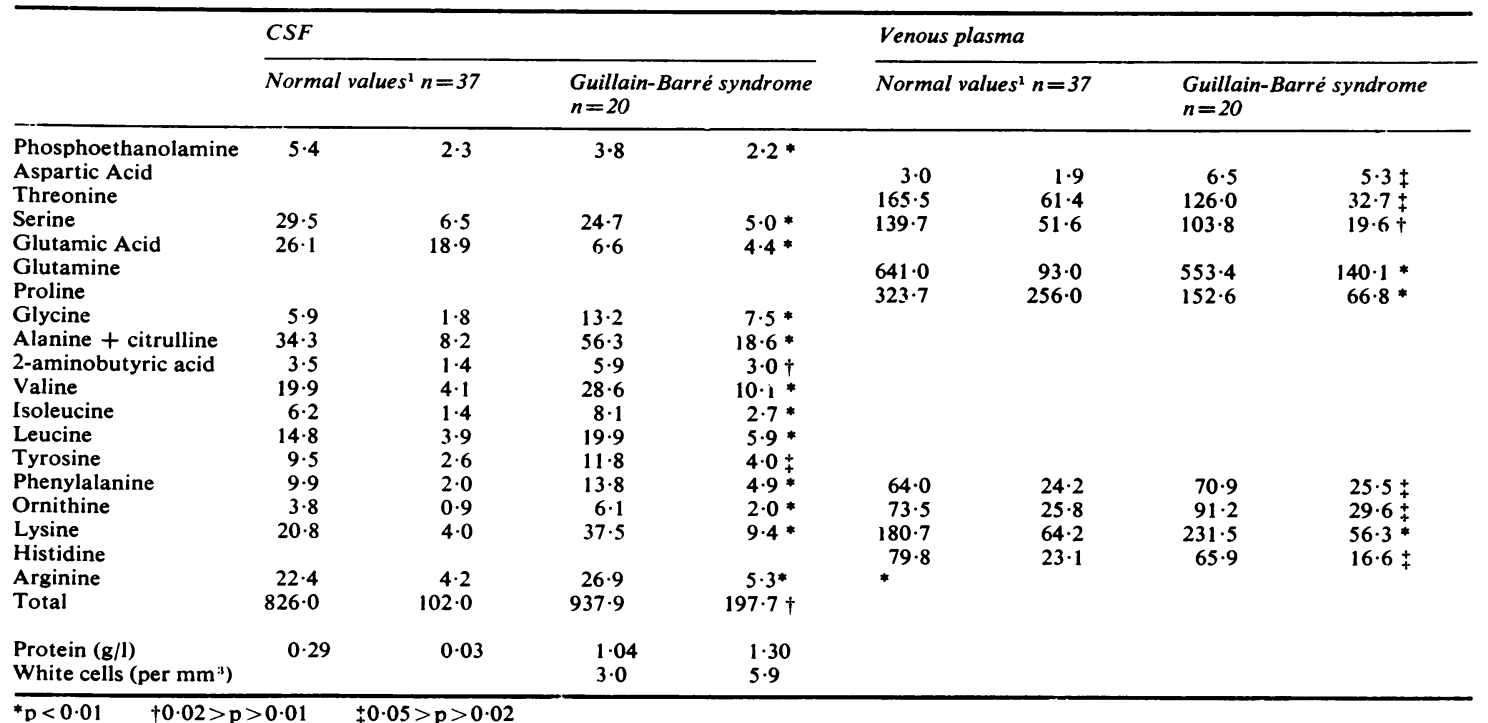


cell count and changes in CSF amino acid concentrations.

\section{Discussion}

In the present study we have shown a disturbance in CSF amino acid composition in patients with the Guillain-Barré syndrome which involved an alteration in concentration of 15 amino acids. These abnormalities were most marked when the CSF protein concentration was raised.

It seems most probable that some of these abnormalities result from a breakdown of the blood-CSF barrier to amino acids. Several observations would support this view. Firstly, there is evidence that the rise in CSF protein concentration in the Guillain-Barré syndrome results from a breakdown of the blood-CSF barrier; ${ }^{7-11}$ in the present study the concentration of 12 amino acids was raised in patients with an elevated CSF protein concentration while only six of these were raised when the protein concentration was normal. Secondly, previous studies from this department and elsewhere done on patients with meningitis have shown that the large increase in CSF protein and amino acid concentrations are most likely to result from a breakdown of the blood-CSF barrier. ${ }^{514}$ In the Guillain-Barré syndrome it is possible that the breakdown of the barrier might occur at the nerve roots where there is evidence that a protein-rich oedema fluid collects ${ }^{15}$ and protein leakage occurs. ${ }^{6}$ Alternatively, an inflammatory reaction might occur in the choroid plexus and disturb the transport processes at this site. ${ }^{16-20}$ Evidence for this latter mechanism is based on the morphological, molecular and functional similarities between the choroid plexus and the renal glomerulus ${ }^{21}$ and the presence of immunological cross-reactivity between these tissues. ${ }^{2-25}$ Since glomerulonephritis has been shown to occur commonly in patients with the Guillain-Barré syndrome ${ }^{26}$ and since there has been histological confirmation of immune-complex nephritis in patients with this syndrome ${ }^{27} 28$ it would seem reasonable to infer that immunological damage might also occur in the choroid plexus. This might be initiated by immune complexes containing circulating antibodies to per1pheral nerve tissue which are known to occur in this syndrome. ${ }^{29}$

In agreement with our earlier studies on normal and patients with meningitis ${ }^{\tilde{r}}$ it is unlikely that changes in plasma amino acid concentrations are an important factor in producing the changes in the CSF since there was a simultaneous increase in CSF and plasma concentrations of only three amino acids. It also seems unlikely that the CSF amino acid changes result from the breakdown of myelin protein during demyelination of the nerve roots which occurs in the Guillain-Barré syndrome $^{30}$ since two of the amino acids present in high concentration in mammalian myelin protein (glutamic acid and serine), ${ }^{31}$ were found in low concentration in the CSF.

Irrespective of the processes involved, disturbance of CSF amino acid profile might be of use in helping to confirm the diagnosis of the Guillain-Barré syndrome. At present the CSF protein concentration is routinely measured but is not always found to be raised. ${ }^{12}$ In this s.udy we have found disturbances of the normal CSF amino acid composition even in the presence of a normal protein concentration.

\section{References}

1 McGale EHF, Pye IF, Stonier C, Aber GM, Hutchinson EC. Studies of the interrelationship between cerebrospinal fluid and plasma amino acid concentration in normal individuals. $J$ Neurochem 1977; 29:291-7.

2 Lakke JRWF, Teelken AW. Amino acid abnormalities in the cerebrospinal fluid of patients with Parkinsonism and extrapyramidal disorders. Neurology (Minneap) 1976; 26:489-93.

3 Mutani R, Monaco F, Durelli L, Delsediumc M. The free amino acids in the cerebrospinal fluid of epileptic subjects. Epilepsia 1974; 15:593-7.

4 Perry TL, Hansen S, Lesk D, Kloster M. Amino acids in plasma, cerebrospinal fluid and brain of patients with Huntington's chorea. Adv Neurol 1973; 1:603-18.

5 Corston RN, McGale EHF, Stonier C, Hutchinson EC, Aber GM. Abnormalities of cerebrospinal fluid amino acids in purulent meningitis. J Neurol Neurosurg Psychiatry 1979; 42:881-6.

6 Rieder HP, Kaeser HE, Nusselt L. Ligmerproteinveranderungen bei Polyneuritis. Schweiz Med Wschr 1972; 102:766-72.

7 Okuyama $\mathrm{H}$. A study of the mechanism of high protein content of cerebrospinal fluid (CSF) in the Guillain-Barré syndrome. RISA diffusion within CSF cavity and transport from CSF to circulating plasma. Clin Neurol (Tokyo) 1975; 15:817-26.

8 Miyazaki M, Fujita M, Genba H, Shimazaki K, Ogawa M. Study on the blood-cerebrospinal fluid barrier (III). Permeability in normal state and in polyradiculoneuritis. Clin Neurol (Tokyo) 1975; 15:843-50.

9 Schliep G, Felgenhauer K. Serum-CSF protein gradients, the blood-CSF barrier and local immune response. J Neurol 1978; 218:77-96. 
10 Behan PO, Currie S. Clinical Neuroimmunol 1978; WB Saunders.

11 Jensen $\mathrm{K}$. Cerebrospinal fluid proteins in neurological diseases. Studies on agar gel electrophoresis protein profiles. Acta Neurol Scan (Suppl) 1978; 58(70): 1-268.

12 National Institute of Neurological and Communicative Disorders. Committee Formulates Definition and Criterions of Guillain-Barré syndrome to Aid in Diagnosis. JAMA 1978; 240:1709-10.

13 Pye IF, Stonier C, McGale EHF. Doubleenzymatic assay for determination of glutamine and glutamic acid in cerebrospinal fluid and plasma. Anal Chem 1978; 50:951-3.

14 Kabat EA, Moore DM, Landow H. An electrophoretic study of protein components in cerebrospinal fluid and their relationship to serum proteins. J Clin Invest 1942; 21:571-7.

15 Haymaker W, Kernohan JW. The LandryGuillain-Barré syndrome, a clinico-pathological report of fifty fatal cases and a critique of the literature. Medicine (Baltimore) 1949; 28:59-141.

16 Cutler RWP, Lorenzo AV. Transport of 1aminocyclo-pentanecarboxylic acid from feline cerebrospinal fluid. Science 1968; 161:1363-4.

17 Lorenzo AV, Cutler RWP. Amino acid transport by choroid plexus in vitro. J Neurochem 1969; 16:577-85.

18 Snodgrass SR, Cutler RWP, Kang ES, Lorenzo AV. Transport of neutral aminco acids from feline cerebrospinal fluid. Am J Physiol 1969; 217: 974-80.

19 Cutler RWP. Transport of lysine from cerebrospinal fluid of the cat. J Neurochem 1970; 17: 1017-27.

20 Snodgrass SR, Lorenzo AV. Transport of Gaba from the perfused ventricular system of the cat. J Neurochem 1973; 20:761-9.

21 McIntosh RM, Koss MM. Editorial. Ann Intern Med 1974; 81:111-2.

22 McIntosh RM, Griswold WR, Chernack, Koss MM. The choroid plexus-a possible role in autoimmune nephritis. Clin Res 1973; 21:324.

23 Koss MM, Chernack WJ, Griswold WR. The choroid plexus in acute serum sickness. Arch Pathol 1973; 96:331-4.

24 Lampert P, Oldstone MBA. Host immunoglobulin $G$ and complement deposits in the choroid plexus during spontaneous immune complex disease. Science 1973; 180:408-10.

25 Atkins CJ, Kondon JJ, Quismorio FP, Frion GJ. The choroid plexus in systemic lupus erythematosus. Ann Intern Med 1972; 76:65-72.

26 Rodrigues-Iturbe B, Garcia R, Rubio L, Zabala $J$, Moros G. Acute glomerulonephritis in the Guillain-Barré-Strohl syndrome. Ann Intern Med 1973; 78:391-5.

27 Faber V, Balslov JT. Immunofluorescent studies of renal biopsies in acute polyradiculitis. Acta Pathol Microbiol Scand (B) 1970; 78:655-6.

28 Behan PO, Lowenstein LM, Stilmant M, Sax DS. Landry-Guillain-Barré-Strohl syndrome and immune complex nephritis. Lancet 1973; i:850-4.

29 Melnick SC. Thirty-eight cases of Guillain-Barré syndrome. An immunological study. $\mathrm{Br} \mathrm{Med} J$ $1963 ;$ i:368-73.

30 Asbury AK, Arnason BG, Adams RD. The inflammatory lesion in idiopathic polyneuritis. Medicine (Baltimore) 1969; 48:173-215.

31 Landon DN ed. The Peripheral Nerve. Chapman and Hall, 1976. 